\title{
Branding "Kampong Parjhuge" sebagai Destinasi Kampung Pendidikan Karakter Mahasiswa di Lingkungan Universitas Trunojoyo Madura
}

\author{
Fachrur Rozi \\ Prodi Ilmu Komunikasi Fakultas Ilmu Sosial dan Ilmu Budaya ( FISIB ) \\ Universitas Trunojoyo Madura \\ E-mail: rozihabibie@gmail.com
}

DOI: https://doi.org/10.21107/ilkom.v14i1.6974

\begin{abstract}
ABSTRAK
Masalah keamanan akhir-akhir ini masih menjadi topik diskusi tanpa akhir di sekitar kampus Universitas Trunojoyo Madura. Problema ini jika tidak ada langkah nyata baik dari pihak berwenang, aparat desa, pemerintah kabupaten, bahkan kampus UTM sendiri akan menimbulkan masalah baru. Tentu saja, penduduk lokal dan mahasiswa UTM akan dirugikan. Mereka akan selalu merasa cemas, dan takut dengan masalah tersebut. Selain itu, perilaku asosial dengan banyak rumah kos dan mahasiswa sewaan menjadi kerumitan masalah baru yang mengarah pada munculnya ide tentang konsep pendidikan karakter di lingkungan UTM. Pengabdian masyarakat yang dikemas sebagai bentuk kegiatan, dan branding desa harapannya desa bisa memiliki ciri khas dan siappun yang berada di desa tersebut mampu mendapatkan perubahan karakter yang lebih baik.
\end{abstract}

Kata kunci : branding, kampong parjhuge, pendidikan karakter.

\begin{abstract}
Security issues lately are still a topic of endless discussion around the campus of the University of Trunojoyo, Madura. This problem if there are no concrete steps either from the authorities, village officials, district government, even the UTM campus itself will cause new problems. Of course, local residents and UTM students will be disadvantaged. They will always feel anxious, and afraid of the problem. In addition, asocial behavior with many boarding houses and rented students is a new problem that leads to the emergence of ideas about the concept of character education in the UTM environment. Community service is packaged as a form of activity, and village branding is expected that the village can have characteristics and anyone in the village is able to get a better character change.
\end{abstract}

Keywords : branding, kampong parjhuge, character education

\section{Cite this as :}

Rozi, Fachrur (2020). Branding "Kampong Parjhuge" sebagai Destinasi Kampung Pendidikan Karakter Mahasiswa di Lingkungan Universitas Trunojoyo Madura. Jurnal Komunikasi, 14(1), 73-82. doi : https://doi.org/10.21107/ilkom.v14i1.6974 


\section{PENDAHULUAN}

Desa adalah bagian yang penting dari suatu masyarakat yang mana tak dapat terpisahkan. Pentingnya desa ini menurut ahli keberadaannya semestinya tidak boleh diremehkan termasuk juga oleh pemerintah karena pentingnya keberadaan desa tersebut. Definisi desa juga ditekankan dan juga diperkuat oleh hukum melalui Undang Undang. UU yang memberikan definisi tentang desa adalah UU No. 5 Tahun 1979 yang menjelaskan bahwa desa adalah suatu wilayah yang ditempati oleh sejumlah penduduk sebagai kesatuan masyarakat termasuk di dalamnya kesatuan masyarakat dan hukum yang mempunyai organisasi pemerintahan terendah langsung dibawah camat dan berhak menyelenggarakan rumah tangganya sendiri dalam ikatan Negara Kesatuan Republik Indonesia.

Definsi desa menurut UU ditambahkan pada UU No. 22 Tahun 1999. Dalam UU tersebut, kembali dijelaskan bahwa desa adalah kesatuan masyarakat hukum yang memiliki kewenangan untuk mengatur dan mengurus kepentingan masyarakat setempat berdasarkan asal usul dan adat istiadat setempat yang diakui dalam sistem pemerintahan Nasional dan berada di daerah Kabupaten.

Keberadaan masyarakat di dalam desa tersebut memberikan pengaruh terhadap karakter dari desa tersebut. Tentunya karakter desa tersebut bisa dijadikan sebuah potensi atau diferensiasi dari desa lain. Diferensiasi tersebut nantinya bisa menjadikan desa tersebut menjadi desa yang aman, nyaman sehingga memberikan rasa betah terhadap penghuninya. Seperti yang kita ketahui desa, atau komplek yang memiliki nilai jual tinggi di masyarakat pasti memiliki keunikan ataupun memiliki kualiatas yang berbeda baik dari keamanan, maupun lokasi yang strategis.

Sebagai contoh Desa telang yang merupakan salah satu desa yang berada di kecamatan Kamal ini memiliki nilai juah tanah yang sangat mahal dibandingkan nilai jual beli tanah pada tingkat kecamatan di Kabupaten Bangkalan. Hal ini disebabkan oleh keberadaan kampus Universitas Trunojoyo Madura. Dimana dalam hal ini para investor mulai melirik lokasi tersebut untuk melakukan investasi berupa rumah kos/kontrakan, ruko, warung, café, dan lainnya untuk bisa mengais rupiah dari aktivitas mahasiswa di sekitar kampus.

Banyaknya investor yang sangat beragam atau sering disebut sebagai pemilik kos/kontrakan menjadikan desa telang ini menjadi areal yang susah di kontrol baik penghuni maupun pemilik bangunannya. Selain itu permasalahan tersebut berkembang pada masalah keamanan baik pencurian maupun tindak kriminal lainnya. Sehingga hal ini menjadikan permasalahan baru terhadap desa telang sendiri.

Wilayah Desa Telang terdiri dari Telang dalam (penduduk asli), Telang Asri (perumahan), Telang Candi (penduduk asli), Telang Indah (perumahan). Lokasi yang bersentuhan langsung dengan lingkungan kampus yaitu dusun Telang Indah. Dusun Telang Indah ini merupakan komplek perumahan dimana hampir sebagian besar ditempati oleh pendatang, baik warga maupun mahasiswa.

Kompleksitas penduduk di Telang menjadikan permasalahan yang perlu segera mendapatkan perhatian khusus dari pihak kampus dan Pemkab Bangkalan sebagai instansi pemerintah yang memberikan dampak utama terhadap situasi Desa Telang saat ini. Tentunya tanggung jawab tersebut diharapkan menjadi sebuah solusi teknis dalam menyelesaikan permasalahan tersebut.

Tanggal 3 Desember 2018 kampus dan Pemkab Bangkalan telah melakukan MoU (Memorandum of understanding) dimana keduanya bersepakat untuk memberikan solusi dari permasalahan yang terjadi di sekitar kampus. Salah satu solusi yang menjadi prioritas utama pada tahun 2019 ini adalah menggagas "Kampung Karakter". Kampung karakter ini diharapkan bisa memberikan sebuah pemahaman atau paradigma baru berupa sebuah gerakan positif dalam membangun mindset atau pemahaman kepada masyarakat terutama dalam menjaga 
kemanan dan kenyamanan kampung telang indah.

Telang indah ini memiliki 7 RT (rukun tetangga) dan $1 \mathrm{RW}$ (rukun warga) yang terbagi menjadi 3 RT bernama Telang indah Barat, dan 4 RT berada di kompleks telang indah timur, Telang cendana, Telang jalan raya kampus. Namun lokasi sementara untuk dijadikan sample awal baik riset dan pelaksanaan kegiatan kampung karakter ini adalah RT 01 - RT 03. Dimana lokasi RT ini merupakan lokasi induk yang ditempati oleh warga dan mahasiswa sebelum berkembang menjadi 7 RT. Selain itu, RT 01-RT 03 sudah memiliki infrastruktur yang mempuni seperti masjid, poskamling, sekolah dan sejumlah portal pembatas.

Isu besar yang kita angkat pada tahap awal kegiatan ini adalah "keamanan". Isu ini sangat diharapkan oleh masyarakat sekitar kampus baik mahasiswa maupun warga agar segera ada solusi dari instansi terkait. Isu ini sangat mengganggu kenyamanan masyarakat dalam aktivitasnya. Dimana seperti yang kita ketahui bahwa di telang menjadi lumbung tindakan kriminalisme.

Sebagai akademisi penulis tidak bisa melakukan banyak terutama di dalam hal yang teknis dalam penanganan kriminalitas. Dalam hal ini penulis dalam kegiatan pengabdian hanya mendesain sebuah kegiatan berupa himbauan akan peningkatan keamanan kampung, dan kegiatan yang bernuansa Pendidikan karakter. Kegiatan ini sebenarnya jauh lebih mendasar dibandingkan dengan sebuah tindakan prakmatis yang dilakukan oleh pihak berwajib.

Kegiatan ini meurpakan sebuah bentuk sinergi, antara warga, ahli (akademinisi), pemerintah, dan pihak penegak hokum dalam menciptakan suasani lingkungan kampus di telang bisa lebih kondusif. Mungkin kita semua sudah paham suasana kos-kosan dan kontrakan di kampuskampus dimanapun potensi tindak kriminal sangat tinggi, kita sebagai akademisi wajib memberikan sebuah pemahaman yang realistis dan factual. Oleh karena itu, kami sebagai pihak pelaksana mengajak baik
Pemkab, Pimpinan Kampus UTM, Mahasiswa, dan warga telang dan sekitarnya untuk ikut berpartisipasi dalam menyukseskan kegiatan ini dalam mewujudkan telang sebagai kampung yang berkarakter Parjhuge.

Latar belakang diatas bisa ditarik sebuah rumusan pada tulisan ini sebagai berikut: Bagaimana kegiatan Kampong parjhuge menjadi branding desa telang indah dalam membentuk karakter mahasiswa di luar kampus UTM. Sementara manfaat tulisan ini adalah menjadikan telang indah sebagai lokasi hunian aman dan nyaman, serta memersiapkan lulusan yang parjhuge (berwibawa) yang memiliki 4 sikap dan sifat Amanah (bertanggung jawab), fathanah (cerdas), tabligh (komunikatif), dan sidik (jujur).

\section{METODE PENELITIAN}

Tulisan ini menggunakan sebuah metode deskriptif kualitatif, dimana penulis disini akan mendeskripsikan sebuah proses pelaksanaan kegiatan dan dampak dari kegiatan tersebut. Teori yang digunakan dalam penulisan ini menggunakan teori citra frank Jefkin (2003: 10) yang menjelaskan Cerminan citra (the mirror image), Citra yang masih hangat (the current image), Citra yang diinginkan (the wish image), dan Citra yang berlapis (the multiple image).

Teori Pendidikan karakter menurut Darmiyati (2006: 5), sistem pendidikan yang sesuai untuk menghasilkan kualitas masyarakat yang berkarakter positif adalah yang bersifat humanis, yang memposisikan subjek didik sebagai pribadi dan anggota masyarakat yang perlu dibantu dan didorong agar memiliki kebiasaan efektif, perpaduan antara pengetahuan, ketrampilan, dan keinginan. Teori ini digunakan untuk mendeskripsikan kegiatan kampung karakter sebagai salah satu Branding desa Telang.

Pelaksanaan kegiatan pengabdian ini dilakukan di desa Telang dan di kampus UTM dan dimulai pembukaan PKKMB (pengenalan kehidua kampus mahasiswa baru 2019) pada bulan Agustus hingga bulan Januari. Peserta 
kegiatan kampung karakter adalah mahasiswa, dan warga sekitar kampus.

\section{HASIL DAN PEMBAHASAN}

Pada pembahasan ini penulis akan mengawali dengan mendeskripsikan pengertian kampung karakter. Istilah kampung karakter sebenarnya juga cukup beragam, namun penulis hanya ingin mendeskripsikan istilah karakter sebagai suatu individu atau kelompok masyarakat atau suatu bangsa yang memiliki karakter yang berbeda-beda (ciri khas). Karakter yang ditunjukkan akan tercermin dalam cara berperilaku dan cara berpikir serta tindakan yang dilakukan secara terus-menerus dalam segala bidang kehidupan. Karakter didefinisakan sebagai panduan daripada segala tabiat manusia yang bersifat tetap sehingga menjadi tanda segala tanda khusus untuk membedakan orang satu dengan orang lain (Andrianto. $2011:$ 17)

Pendapat lain dari Thomas Lickona dalam Agus Wibowo (2012: 32) mendefinisikan bahwa "karakter merupakan sifat alami seseorang dalam merespons situasi secara bermoral. Sifat alami itu dimanifestasikan dalam tindakan nyata melalui tingkah laku yang baik, jujur, bertanggung jawab, menghormati orang lain dan karakter mulia lainnya".

Selain itu, Karakter merupakan nilainilai perilaku manusia yang berhubungan dengan Tuhan Yang Maha Esa, diri sendiri, sesama manusia, lingkungan dan kebangsaan yang terwujud dalam pikiran, sikap, perasaan, perkataan, dan perbuatan, berdasarkan normanorma agama, hukum, tata krama, budaya dan adat istiadat (Masnur Muslich, 2011: 84).

Pengertian dasar tentang karakter itu bila digandengkan dengan istilah kampung penulis mendefinisikan sebagai suatu daerah atau Kawasan yang di desain memiliki karakteristik baik dari bentuk fisik bangunan, Kawasan/lingkungan, maupun karakteristik yang bisa bernilai unik, dan berbeda dengan daerah lain. Tentunya dalam mendesain sebuah kampung yang berkarakter terdapat sesuatu yang lebih spesifik untuk dijual, dirasakan, dilihat, dan di manfaatkan untuk yang lebih baik.

Seperti istilah yang diangkat dalam branding kampung karakter ini adalah "kampong Parjhuge" istilah dalam Bahasa Madura halus memiliki yaitu berwibawa. Istilah Parjhuge ini sering di identikkan sebutan pada penilaian atas kewibawaan seorang raja. Indikator berwibawa menurut penulis adalah bertangguang jawab (amanah), jujur (sidik), komunikatif (tablig), fathanah (cerdas).

Daerah yang dijadikan objek dalam kajian tulisan ini adalah desa telang dimana desa ini menurut sejarah desa ini dinamakan Desa Telang karena menurut cerita bahwa dulu ada seorang pengemis yang membawa padi yang lumayan banyak. Padi itu dipikul dengan bambu sepanjang satu meter dan juga membawa seekor kerbau karena lelah pengemis itupun beristirahat di tengah-tengah jalan yang di sebelah kanan dan kiri merupakan sawah. Pengemis itu meletakkan padi dan bambu serta kerbaunya malang melintang di jalan lalu desa itu dinamakan Desa Telang. Oleh Karena itu Desa Telang merupakan desa yang tidak pernah kekurangan padi dan kerbaunya. Dengan demikian sejarah itu dibuktikan dengan banyaknya sawah yang dibajak dengan kerbau dan menghasilkan padi dan masyarakatnya makmur. Walaupun sejarah tersebut singkat namun memberikan makna yang sangat berarti bagi masyarakat Desa Telang.

Namun Desa Telang ini sejak tahun 2000an mengalami perubahan yang sangan pesat. Hal ini dikarenakan adanya penegerian salah satu kampus swasta yang bernama kampus Universitas Bangkalan menjadi Universitas Trunojoyo Madura. Hampir tiap tahun perkembangan jumlah mahasiswa dari tahun ketahun meningkat tajam hingga mencapai 1500 mahasiswa tiap tahunnya. Tentunya peningkatan tersebut membuat segala sektor juga ikut meningkat terutana harga tanah, perekonomian masyarakat sekitar juga terkena dampak dari perkembangan kampus tersebut. 
Seperti yang dijelaskan pada latar belakang diatas menunjukkan bahwa, dibalik perkembangan kampus yang begitu pesata juga terdapat sisi kekurangan seperti tindakan asosial. Tindakan asosial ini juga banyak kategorinya namun secara spesifik penulis mendeskripsikan tindakan asosial ini bisa disebut sebagai tindakan kumpul kebo, pencurian, dan kriminal lainnya. Munculnya tindak asosial disebabkan banyaknya koskosan dan kontrakan mahasiswa yang tidak diketahui pemiliknya, artinya mereka (pemilik) tidak bertanggung jawab atas hunian yang disewakan tersebut. Tentu ini sangat bertentangan dengan budaya masysarakat madura pada umumnya. Kita tahu bahwa madura hingga saat ini masih sangat kental nilai-nilai religinya.

Tahun ke 18 kampus UTM ini berdiri pemerintah kabupaten bangkalan bersama pimpinan UTM berkomitmen dengan membuat sebuah MoU yang berisikan tentang pembangunan kampung yang berkarakter. Meski bukan pembangunan fisik namun tolak ukur keberhasilan dari gagasan kampung karakter ini mampu memberikan sedikit perubahan bagi lingkungan kampus (Desa Telang) yang hampir sebagian besar dihuni oleh mahasiswa UTM.

Berdasarkan hasil pengabdian selama bulan Agustus-Desember 2019 tim kampung karakter telah melakukan berbagai kegiatan seperti akreditasi koskosan dan kontrakan, kajian umum (Pendidikan karakter), Kajian agama. Pengabdian masyarakat berupa kegiatan ini menjadikan sebuah hal positif berupa branding desa telang indah sebagai kampung parjhuge.

\section{Branding Kampung Telang Indah}

Opsi pertama dalam merealisasikan sebuah gagasan yang bertujuan untuk pengembangan suatu daerah salah satunya dengan metode pemberian nama yang baik (branding). Tentunya penamaan atau labelisasi dengan istilah yang khas terhadap suatu kawasan menjadi sebuah harapan yang baik demi kemajuan daerah itu sendiri.
Meski diatas sekilas istilah kampung karakter telah disebut diatas, tentunya penulis perlu menjelaskan secara detail bagaimana proses tersebut bisa memunculkan sebuah nama yang bisa mewakili bahkan bisa menjadi harapan desa tersebut. Sebelum memunculkan sebuah nama penulis tentunya melakukan sebuah pemetaan lokasi/mapping, FGD warga dan tokoh masyarakat setempat, dan kajian ilmiah.

Penulis mengawali deskripsi tulisan ini dengan sebuah teori citra Frank Jefkins (2004: 10) yang dikategorikan sebagai berikut:

1. Cerminan citra (the mirror image), yakni citra berasal dari sebuah dugaan publik eksternal terhadap lingkungan. Artinya kampung Telang Indah yang berada di sekitar kampus UTM ini memiliki banyak perumahan yang dihuni mahasiswa sehingga menjadi lingkungan yang padat dan susah di kontrol. Wajar saja jika publik secara umum berpresepsi kurang baik terhadap kahidupan mahasiswa di luar kampus.

2. Citra yang masih hangat (the current image), yakni citra yang belakangan sering di dapat oleh khalayak luas. Seperti yang kita ketahui tiap kali terjadi tindak kriminal seperti pencurian, pembegalan, hingga tindakan mesum yang dilakukan oleh oknum mahasiswa, seakan merepresentasikan prilaku mahasiswa UTM secara umum. Hal ini sungguh membuat warga setempat dan pimpinan kampus merasa geram.

3. Citra yang diinginkan (the wish image), yakni citra yang sebanarnya diharapkan oleh masyarakat dan kampus yaitu lingkungan yang aman, nyaman, dan benar-benar mengangkat nilai-nilai luhur Madura seperti nilai religius.

Tentunya ada beberapa hal yang perlu ditekankan menurut Frank Jefkins (2004:15):

1. Personality. Disini diartikan sebagai pembentukan karakter atau kepribadian elemen yang berada di dalam kawasan tersebut. Seperti yang dilakukan pada 
kegiatan kampung karakter adalah pendidikan karakter yang diisi dengan topik-topik kekinian, dan kajian keagamaan, serta pengembangan softskill dibidang kerajinan tangan dan lain sebagainya;

2. Reputation, mendesain sebuah kegiatankegiatan yang positif yang mendukung rencana besar dari branding kampung telang indah ini sehingga mampu mengangkat reputasi kampung telang indah. Kegiatan ini diberi nama akreditasi koskosan dan kontrakan. Kegiatannya diawali dengan pendataan kos-kosan dan kontrakan mahasiswa yang berada di areal RT 01-RT 03. Kegiatan ini bertujuan untuk mendata ulang mahasiswa yang berada di kawasan perumahan Telang Indah Persada sebagai lokasi utama kampung karakter ini. Selain itu, pendataan ini juga bertujuan membentuk paguyuban kos-kosan dan kontrakan yang tidak lain untuk membangun komunikasi yang baik demi terciptanya lingkungan yang aman dan nyaman. Kos-kosan dan kontrakan yang telah di data dan dinilai akan mendapatkan labelisasi untuk direkomendasi sebagai kos-kosan dan krontrakan yang layak untuk mahasiswa UTM.

3. Values/Ethics, menanamkan nilai-nilai positif seperti membiasakan diri menjaga kebersihan lingkungan, melakukan siskamling, membangun komunikasi yang inten antar warga. Item ini tidak lain hanya ingin meningkatkan dan mewujudkan kualitas lingkungan yang aman dan nyaman serta hunian ramah untuk di huni oleh warga dan mahasiswa. Harapanya tidak lain seperti isi dari MoU Pemkab Bangkalan dan Pimpinan UTM yakni membangun kampung yang berkarakter guna menerapkan nilai-nilai yang beradab.

4. Corporate identity, mendesain simbol, dan logo dengan istilah yang baik. Istilah yang muncul dari hasil FGD warga yaitu "kampong parjhuge".

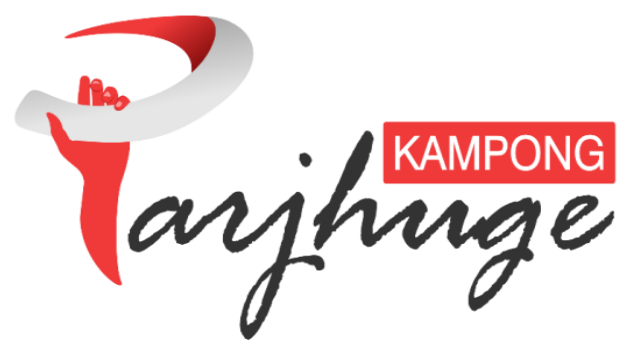

Gambar 1 : Logo branding kampong karakter Parjhuge

Istilah ini dalam Bahasa Madura halus memiliki yaitu berwibawa. Istilah Parjhuge ini sering di identikkan sebutan pada penilaian atas kewibawaan seorang raja. Indikator berwibawa menurut penulis adalah bertangguang jawab (amanah), jujur (sidik), komunikatif (tablig), fathanah (cerdas).

Harapannya citra dan realitas mahasiswa UTM yang hidup dilingkungan kampus UTM (Kampung Telang Indah) ini mampu memiliki seperti yang dimiliki oleh rosul. Selain itu juga mampu menerapkan nilai-nilai yang selama ini digaungkan di dalam kampus yaitu peduli dan kreatif.

Proses terbentuknya citra perusahaan menurut Hawkins et al. (2000: 55) diperlihatkan pada gambar sebagai berikut :

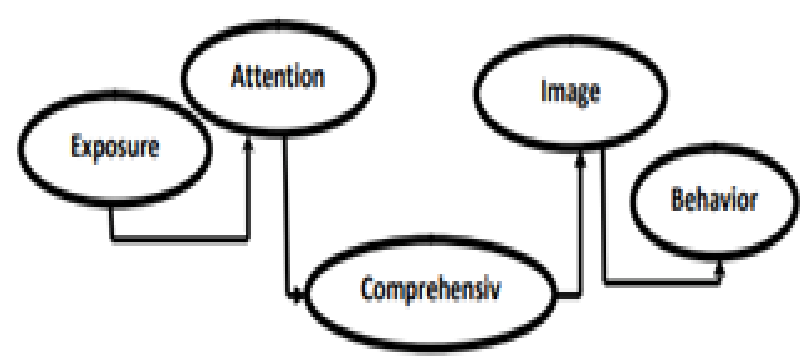

Gambar 2 : Proses terbentuknya prusahaan

Berdasarkan Gambar diatas Kasali (2003: 10) mengemukakan, "Pemahaman yang berasal dari suatu informasi yang tidak lengkap menghasilkan citra yang tidak sempurna" proses terbentuknya citra perusah aan berlangsung pada beberapa tahapan. Pendapat ahli diatas menjadi sebuah refrensi penulis untuk mendeskripsikan tentang peran kampus dan perangkat desa dalam menyukseskan kegiatan ini. 
Pertama, istilah Kampong Parjhuge ini telah resmi di lauching tanggal 3 Agustus 2019 di acara PKKMB 2019. Kedua, kegiatan yang dirancang secara sistematis ini terbukti setiap mahasiswa yang terlibat dalam kegiatan di kampung ini bisa mendapatkan kredit poin sebagai penunjang softskil mahasiswa. Sehingga jika sebelumnya kegiatan di kampung jarang sekali mahaiswa terlibat, dengan peraturan baru ini diharapkan mahasiswa diluar kampus mampu berkegiatan yang lebih positif dari sebelumnya. Ketiga, sistem yang dirancang pada item kedua ini tidak lain untuk menyukseskan kegiatan branding kampong parjhuge ini. Artinya kesuksesan tersebut bisa dihasilkan jika simbiosis mutualisme antara kampus dan kampung, antara mahasiswa dan warga bisa sejalan seirama dalam mengikuti semua kegitan yang telah dirancang oleh tim atau pelaksana kegiatan; Keempat, sehingga bila kegiatan telah tersistem dengan baik terutama dari schedule, peraturan, hingga materi kegiatan tersebut, maka output dari kegiatan kampung karakter ini bisa semakin jelas.

\section{Pendidikan Karakter Di Desa Telang}

Konsep pendidikan karakter yang nantinya akan diterapkan pada desa kampung Telang Indah merupakan serangkaian program untuk mendukung kegiatan branding dari kampung Telang tersebut. Tentuya branding dilakukan tidak lain untuk visualisasi, dan pendidikan karakter untuk menguatkan dari kualitas dari branding tersebut.

Seperti yang dijelaskan di atas bahwa kampong parjhuge memiliki arti yang sangat mendalam, artinya konsep besar untuk melahirkan generasi yang berkualitas di kampung telang yang berada di sekitar kampus ini bisa sejalan dengan branding yang direncanakan.

Menurut Kementerian Pendidikan Nasional (2010: 4) pendidikan karakter dimaknai sebagai pendidikan yang mengembangkan dan karakter bangsa pada diri peserta didik sehingga mereka memiliki nilai dan karakter sebagai karakter dirinya, menerapkan nilai-nilai tersebut dalam kehidupan dirinya, sebagai anggota masyarakat, dan warganegara yang religius, nasionalis, produktif dan kreatif.

Sementara pendidikan karakter menurut Thomas Lickona adalah pendidikan untuk membentuk kepribadian seseorang melalui pendidikan budi pekerti., yang hasilnya terlihat dalam tindakan nyata seseorang yaitu tingkah laku yang baik, jujur, bertanggung jawab, menghormati hak orang lain, kerja keras, dan sebagainya.

Pendapat ahli diatas bila deskripsikan dengan visi dan misi besar dari pendidikan karakter di Kampong Parjhuge Desa Telang Indah ini tidak lain untuk men-support kegiatan kampus yang positif. Selain itu, kegiatan ini juga sebagai bentuk untuk mewujudkan MoU anatar kampus UTM dan Pemkab Bangkalan tahun 2018. Adapun kegiatan yang dirancang dalam kampung karakter "kampong Parjhuge" sebagai berikut:

\section{Akreditas kos-kosan dan kontrakan}

Kegiatan ini merupakan salah satu kegiatan unggulan dari program kampung karakter, karena berdasarkan isu yang diangkat tentang keamanan. Dimana Telang Indah Barat merupakan zonasi mahasiswa yang rawan kriminalitas dan perbuatan Asosial karena banyaknya kos-kosan dan kontrakan tidak memiliki aturan yang jelas terkait hal tersebut. Akreditasi ini juga sebagai bentuk kepedulian kampus UTM terhadap kondusifitas lingkungan sekitarnya.

Seperti yang disebutkan diatas, kegiatan ini dilaksanakan atas kerjasama tim volenter dan tim kampung karakter untuk membantu perangkat desa mendata mahasiswa yang berada di komplek "kampong Parjhuge" (Rt 01-Rt 03/ gang Igang VI). Jika selama ini mahasiswa yang berada di daerah ini keluar masuk tanpa izin, kedepan "kampong Parjhuge" semua warga dan mahsiswa yang tinggal di areal tersebut akan terdata dengan baik. 
Selain itu, serangkaian kegiatan akreditasi ini juga akan membentu paguyuban pemilik kons-kosan dan kontrakan dengan maksud membangun komunikasi yang baik guna membangun dan mengajak peduli atas lahannya. Selama ini pemilik kos-kosan sangat jarang komunikasi dengan pihak ketua RT dan RW terkait keberadaan huniannya. Sehingga mereka hanya layaknya seorang investor yang tidak peduli terhadap dampak dari huniannya terhadap lingkungan sekitar.

Jika nantinya paguyuban ini bisa terbentuk dengan baik, dampak positif yang dirasakan oleh pemilik kos-kosan dan kontrakan adalah mereka bisa memantau koskosannya tersebut dengan baik. Selain itu, nilai positif lainnya adalah bagi perangkat desa bila mana terdapat informasi penting untuk warga di "kampong Parjhuge" bisa cepat sampai, dan yang terakhir bisa menekan angka kriminalitas di lingkungan "kampong Parjhuge"/ kampung Telang Indah Persada.

Kemudian adanya akreditas kos-kosan dan kontrakan ini juga bisa membantu meningkatkan nilai jual dari harga kos-kosan dan kontrakan tersebut, karena hunian tersebut akan di labeliasasi dan di rekomendasi oleh kampus UTM sebagai koskosan dan kontrakan yang ramah lingkungan.

\section{Kajian Keterampilan dan Pendidikan Karakter}

Kegiatan ini dirancang untuk bisa mewadahi kegiatan mahasiswa dan warga di luar kampus. Kegiatan ini juga dilaksanakan setiap 2 minggu-an dengan kegiatan kajian dan praktek keterampilan yang dilaksanakan di areal "kampong Parjhuge" tepatnya di aula Madrasah Masjid Baitus salam.

Selain untuk menguatkan nilai-nilai produktifitas mahasiswa diluar kampus, mahasiswa sejak angkatan 2019 akan diberlakukannya kurikulum kemahasiswaan. Dimana mahasiswa yang ikut terlibat aktif dalam kegiatan di "kampong Parjhuge" akan mendapatkan kredit poin yang diakumulasikan pada (skpi) surat keterangan pendamping ijazah.
Dengan inilah kampus dan warga sekitar berkomitmen memberikan sebuah desain perubahan untuk pengembangan karakter mahasiswa, guna mempersiapkan mahasiswa yang lebih baik saat lulus nantinya.

\section{Kajian keagamaan.}

Dalam rangka menguatkan nilai-nilai religius mahasiswa UTM dan warga Telang Indah. Kegiatan kajian keagamaan ini menjadi salah satu kegiatan yang di laksanakan di masjid Baitus Salam kerjasama antara pihak kampus dan takmir masjid setempat. Tujuannya selain meningkatkan nilai keagamaan juga meningkatkan pengetahuan dalam bidang keagamaan. Harapannya kedepan lulusan mahasiswa UTM ini mampu memberikan kontribusi positif di bidang hardskill maupun softskill saat terjun di masyarakat nantinya.

Kajian keagamaan ini membahas tentang kajian yang ringan-ringan terutama dalam kehidupan sehari-hari, seperti Fiqih, Mualamah, dan kajian Islam secara umum lainnya. Selain itu, untuk mendukung kegiatan takmir masjid Baitus Salam kegiatan ini di dukung penuh oleh dosen-dosen dari Fakultas Keislaman dari UTM sendiri.

\section{Zero waste lifestyle}

Kegiatan ini tidak lain untuk mengendalikan produksi sampah setiap harinya khususnya pada sampah berbahan plastik. Kegiatan ini berupa kampanye pada kegiatan-kegiatan yang ada di Desa Telang. Harapannya kegiatan ini mampu menjadi percontohan di daerah lain. Hal ini mengingat limbah sampah menjadi perhatian kita semua. Sehingga belakangan kita mulai melakukan kegiatan yang meminimalisir penggunaan limbah sampah plastik. Serta kegiatan pengajian ibu-ibu PKK mulai diajak untuk tidak menggunakan air mineral kemasan plastik. 


\section{Membangun Jaringan Komunikasi}

Jaringan komunikasi yang akan di buat berupa sosial media seperti Facebook, Handitalky, dan Instagram. Sosial media ini selain untuk media publikasi dan komunikasi juga dijadikan sebuah media untuk menekan angka kriminalistas dilingkungan sekitar kampus. Seperti HT yang menggunakan frekuensi radio pancar ulang milik UTM, sehingga warga dan mahasiswa yang terkoneksi dengan media tersebut bisa terpantau oleh pihak keamanan setempat.

Hal yang sama seperti penggunaan group tertutup di sosial media FB, dimana mahasiswa yang ingin bergabung dalam group tersebut harus menyertakan nomor induk Mahasiswa (NIM), dan warga menggunakan NIK. Sehingga ini menjadi validasi admin untuk mengetahui anggota group benar benar dari mahasiswa UTM dan warga. Group ini terintegrasi dengan petugas puskesmas, polres, polsek, perangkat desa dan pihak keamanan kampus.

Bilamana terdapat sesuatu yang mencurigakan yang mengarah pada tindak kriminal dan keadaan darurat maka anggota group bisa dengan mudah mengetik di dalam group dan bisa tersambung dengan pihak berwajib

\section{PENUTUP}

Kegiatan kamung karakter ini pada dasarnya merupakan sebuah tantangan dan harapan untuk Pemkab Bangkalan dan kampus UTM untuk menjawab isu yang belakangan sering viral tentang isu keamanan dan isu tindakan asosial dilingkungan mahasiswa. Tentu harapan besarnya adalah menciptakan situasi lingkungan yang kondusif untuk mahasiswa UTM dan warga telang indah persada.

\footnotetext{
Kegiatan kampung karakter ini bukan semata-mata hanya ingin meningkatkan citra desa telang, melainkan untuk mewujudkan suasasa lingkungan desa
}

telang dan kampus UTM lebih kondusif dan mampu menjadikan kampung Telang menjadi hunian yang bisa melahirkan karakter yang lebih baik bagi mereka yang ada di dalamnya (mahasiswa dan warga sekitar).

Selain itu, bagi mahasiswa UTM ini diharapkan mampu berpartisipasi aktif dalam kegiatan yang telah dirancang oleh panitia dan volunter guna melahirkan suasana yang kondusif dan mempersiapkan lulusan yang memiliki karakter kuar seperti branding dari kampung karakter yakni mahasiswa Parjhuge/berwibawa yang memiliki sifat Amanah, Fathanah, Tabligh, Sidiq, Peduli, dan Kreatif.

\section{DAFTAR PUSTAKA}

Andrianto, Tuhana Taufiq. 2011 Mengembangkan Karakter Sukses Anak di Era Cyber. Jogjakarta: Arruz Media.

Hawkins, D. I. et al. 2000. Consumer Behavior : Building Market Strategy 8 Edition. Boston: Mc Graw Hill

Jefkin, Frank. 2004. public relations edisi kelima, Jakarta : PT Gelora Aksara

Kasali, Rhenald. 2003. Manajemen Public Relation. Jakarta. Grafiti

Kementerian Pendidikan Nasional. (2010). Pengembangan Pendidikan Budaya dan Karakter Bangsa. Jakarta: Kementerian Pendidikan Nasional Badan Penelitian dan Pengembangan Pusat Kurikulum

Mansur, Muchlis. 2011. Pendidikan Karakter Menjawab Tantangan Kritis Multidimensional. Jakarta: Bumi Aksara

Undang-Undang No.22 Tahun 1999 tentang Pemerintah Daerah

Undang-Undang No.5 Tahun 1979 tentang Pemerintah Desa 
82 | Jurnal Komunikasi, Vol. 14 No. 01, Maret 2020: 73-82

Wibowo, Agus. 2012. Pendidikan Karakter. Yogyakarta: Pustaka Pelajar.

Zuchdi, Darmiati. (2006). Pendidikan
Karakter (Konsep Dasar dan Implementasi di Perguruan Tinggi). Yogyakarta: UNY Press 